\title{
Potato Trading Based on Structure Conduct Performance (SCP) in the Centre of Vegetable Production at Central Java Indonesia
}

\author{
Pujiharto $^{1} \&$ Sri Wahyuni ${ }^{2}$ \\ ${ }^{1}$ Faculty of Agriculture, Universitas Muhammadiyah Purwokerto, Indonesia \\ ${ }^{2}$ Faculty of Economics and Bussiness Universitas Muhammadiyah Purwokerto, Indonesia \\ Correspondence: Pujiharto, Faculty of Agriculture, Universitas Muhammadiyah Purwokerto, Indonesia.
}

Received: December 11, 2019

Accepted: January 18, 2020

Online Published: March 9, 2020

doi:10.5430/rwe.v11n1p171

URL: https://doi.org/10.5430/rwe.v11n1p171

\begin{abstract}
This study aims to examine potato trading based on Structure, Conduct, Performance (SCP) in the highland vegetable production centers of Central Java Province. Potato trading in highland vegetable production centers in Central Java province has been analyzed using Structure, Conduct, and Performance (SCP) techniques. The data was collected through a survey and observation. The market structure was analyzed by market share, the Herfindahl-Hirschman Index (HHI) and the Concentration Ratio for Biggest Four (CR4). Analysis of market behavior includes the presence or absence of collusive practices in determining prices, the process of selling and buying, the formation of equilibrium prices, payment systems (cash, credit), and cooperation with other trading institutions. While market performance is analyzed by marketing margins and farmer's share. The samples of potato farmers were determined by the random sampling method and the traders determined by the snowball sampling method. The number of samples used was 82 potato farmers, 45 collecting traders, 10 wholesaling traders, and 14 retailing traders. The results of market structure research on potato trading are oligopsonies. Price behavior at farmers (producer) level is more controlled by collectors who deal directly with farmers. Wholesalers dominate purchases from collectors, the payments are made in cash or paid later. Moreover, the collusive practice between collectors and wholesalers occurs, especially in the provision of capital or credit. Furthermore, the performance of the potato market based on the trading system margin is greatest in pattern 2, while the farmer's share is greatest in pattern 1 in the potato trading system.
\end{abstract}

Keywords: potato trading, structure, conduct, performance

\section{Introduction}

The potato is cultivated in much of the world as a convenient, shelf-stable food, and rich in nutrients for the fulfillment of society nutrition (Camire, 2016; Sadeghpour et al, 2017). The increase of potato production needs to be continued in line with the increase in population. A large amount of production and consumption of potatoes does not yet reflect efficient marketing; it needs to be balanced with a fair marketing system that benefits the whole entrepreneur. As an entrepreneur, farmers have an experience in welfare that declined with the classic problems in it, such as inconsistencies in the number and quality of products produced, low productivity, and long marketing chains with market conditions that are not well organized, all of which are further become part of the problem of the potato trading system. The main problems faced by potato trading are generally carried out according to the custom and lasted for some generations so that they do not meet the standards of trading that needed at this time. The high price on potato products at the consumer level due to inefficient running of the trading process, there are a long trading chain, high transportation costs, and loading and unloading.

Based on the problems that have been described before, this study examines potato trading based on Structure, Conduct, Performance (SCP) in the highland vegetable production centers of Central Java Province. Structure analysis describes the size of the market share and market concentration. Furthermore, Conduct describes behavior in the sales and purchase process, the formation of equilibrium prices, payment systems (cash or credit), and cooperation with other trading institutions. Whereas, the Performance shows the efficiency level of the potato trading system.

\section{Literature Review}

In this global agriculture era, potato and its processed products have great market potential and become a primary part of the global agricultural trade as well (Wang et al., 2016). An increase in potato yield calls for improvement of the 
quality of potato production and marketing systems (Hirpa et al., 2010). Moreover, farmer market access is a vital component of market participation. A smallholder farmer can access the market by physically transporting the produce to the market place using available means or selling to a buyer at the farm gate (Sebatta et al., 2014).

Although nowadays the policy is oriented in smallholder farmers, they still have to compete for markets with the already developed commercial sector. For this reason, their survival in the markets competition is still hard. In output markets, smallholder farmers often faced some obstacles in enforcing contracts, lack skills, located in remote areas, and mostly rely on middlemen (Jari \& Fraser, 2009). The obstacles that often faced by smallholder farmers are farmers have limited access to marketing information, services, technology, and capital. This lack of access restricts the small-holder farmers to participate efficiently in the marketing of their produce (Bonabana-Wabbi et al., 2013). So, the farmer often sells their product not directly to their consumer.

In potato marketing chain there are some actors that play an important role including collectors, retailers, transporters, wholesalers and farmers. Because of the indirectly selling system, so the terms of production, processing, procurement, payment, and product type are set by buyers and not producers (Bonabana-Wabbi et al., 2013). The relationship between buyer and supplier are characterized by trust and commitment. Buyers achieve greater benefits from consistently receiving from suppliers' best prices, better value, and the ability to obtain needed products in short supply. And, the suppliers achieve greater buyers' loyalty and receive higher repeat sales.

On the other hand, the reciprocal buying may potentially lower the bargaining position of the farmers, they might have had unfavorable experience with the reciprocal buying arrangements on this marketing chain (Mulyo Aji, 2016). The uncertainty of commodity prices makes a farmer has a risk of receiving a price lower than the expected price for his yield product (Srinivasan, 2011).

The Structure, Conduct, and Performance (SCP) paradigm explained that an industry's performance depends on the conduct of suppliers and consumers which are determined by the structure of the market (Lam et al., 2007). SCP analysis combines economic theory and empirical observations of market experience to help and understand the operations of markets and their contribution to economic development (Bukar et al., 2015). Moreover, SCP was developed from the classical analysis of markets, aiming at measuring and analyzing the relationship degree that exists among market structures, conduct, and performance (Ebenezer \& Oladipo, 2016).

Market structure analysis emphasizes of market competition and attempts to relate the variables of market performance to types of market structure and conduct (Ekunwe \& Alufohai, 2009). Market structure refers to the scale and number of distribution of buyers and sellers, entry barriers, product differentiation, and scale economies. These factors are generally considered to affect the level of competition in a market (Teece, 2016).

Market conducts deals with the behavior of firms, those price-makers are expected to act differently from those in a price taker type (Ekunwe \& Alufohai, 2009). Market conduct refers to the behavior and practice of firms in the market, price policies and other policies pursued by the sellers (Eronmwon et al., 2014), degree of collusive activity, product advertising, and innovative behavior (Lam et al., 2007). Market conduct comprises of various decision-making techniques in determining prices, output, and sales promotion to achieve their goals (Lelissa \& Kuhil, 2018). Market conduct serves as an important bridge to linking between market structure and performance (Lam et al., 2007).

In market performance, there is a marketing margin that has remained as an important tool in analyzing the performance of marketing systems. The cost of the market and the profit margins which make up marketing margins can be indicators of efficiency or inefficiency marketing systems (Achike \& Anzaku, 2010). The importance of market performance lies in the implication that an outcome that in some way or another is better than other outcomes (Martin, 2012) and in this research the market chain of potatoes trading will be analyzed using SCP analysis. The key issue for matching the data is that the researcher learns about the mean growth rate of stock prices from the past with observation (Adam et al., 2016; Razavi et al, 2015).

\section{Research Methods}

This research was conducted in Banjarnegara Regency, Central Java, Indonesia, which was determined purposively. The basic method that used in this study is the descriptive analysis method, which is to calculate, describe, and summarize collected research data in a logical, meaningful, and efficient way (Vetter, 2017). The data was collected through surveys and observation techniques. Traders samples were determined by the snowball sampling method, with the number of traders 45 people, wholesalers 10 people, and retailers 14 people. Meanwhile, for the sample of farmers determined through random sampling, the number of potato farmers is 82 . 


\subsection{Data Analysis Methods}

The research data that obtained were analyzed descriptively and quantitatively. Descriptive analysis to obtain a broad picture of various aspects of trading and related factors, thus supporting quantitative analysis which is analyzed by:

\subsection{Market Structure Approachment}

\section{a. Market Share}

Market share is the total percentage of sales in a target market that obtained from a company, and according to Aguiar et al., (2017) can be calculated using this equation:

$$
M S_{i}=\frac{s_{i}}{S_{t o t}} \times 100 \%
$$

Where $\mathrm{MS}_{\mathrm{i}}$ is the $\mathrm{i}$-th company market share $(\%), \mathrm{S}_{\mathrm{i}}$ is a sales or production capacity of the $\mathrm{i}$-th company (Brezina et al, 2016), and $S_{\text {tot }}$ is the total sales or total production of the entire company. Table 1 presents some components used in the analysis of market share.

Table 1. Market share of market institution (Company)

\begin{tabular}{|c|c|c|c|c|}
\hline $\begin{array}{l}\text { Market } \\
\text { Institution } \\
\text { (Company) }\end{array}$ & $\begin{array}{l}\text { Production Capacity that } \\
\text { Absorbed by a Market Area }\end{array}$ & $\begin{array}{l}\text { Concentration } \\
\text { (Cr) }\end{array}$ & Ratio & $\begin{array}{l}\text { Market Share } \\
(\%)\end{array}$ \\
\hline 1 & A & $\mathrm{a} / \mathrm{x}$ & & $(\mathrm{a} / \mathrm{x}) .100$ \\
\hline 2 & B & $\mathrm{b} / \mathrm{x}$ & & $(\mathrm{b} / \mathrm{x}) .100$ \\
\hline 3 & $\mathrm{C}$ & $\mathrm{c} / \mathrm{x}$ & & $(\mathrm{c} / \mathrm{x}) .100$ \\
\hline 4 & $\mathrm{D}$ & $\mathrm{d} / \mathrm{x}$ & & $(\mathrm{d} / \mathrm{x}) .100$ \\
\hline$\ldots$ & $\ldots$ & $\ldots$ & & $\ldots$ \\
\hline $\mathrm{N}$ & $\mathrm{M}$ & $\mathrm{m} / \mathrm{x}$ & & $(\mathrm{m} / \mathrm{x}) .100$ \\
\hline Total & $\mathrm{a}+\mathrm{b}+\mathrm{c}+\mathrm{d}+\ldots+\mathrm{m}=\mathrm{x}$ & 1 & & 100 \\
\hline
\end{tabular}

With criteria:

a. Pure monopoly, if a company has a $100 \%$ share of the market share,

b. the dominant company if it has $80-100 \%$ of the market share and without strong competitors,

c. oligopoly (tight oligopsony), if 4 leading companies have $60-100 \%$ of the market share,

d. oligopoly (loose oligopsony), if 4 leading companies have $40 \%$ to less than $60 \%$ market share,

e. monopolistic competition, if there are many effective competitors, none of which have more than $10 \%$ market share,

f. pure competition, if more than 50 competitors, but none of which have a meaningful market share.

b. Herfindahl-Hirschman Index (HHI)

The Hirschman-Herfindahl Index is the sum of the squared values of all market shares in a given market area (Shepherd, 1987). This analysis aims to determine the concentration degree of buyers from a market area so that it can be known generally that the balance of the bargaining position of farmers (sellers) against traders (buyers). According to Mcauliffe (2015) and Naldi \& Flamini (2014), the Herfindahl-Hirschman Index equation is:

$$
\mathrm{HHI}=\left(\mathrm{Ms}_{1}\right) 2+\left(\mathrm{Ms}_{2}\right) 2+\ldots .+(\mathrm{Msn}) 2
$$

where $\mathrm{HHI}$ is Herfindahl-Hirschman Index, $\mathrm{n}$ is the number of traders in a product market area, and $\mathrm{Ms}_{\mathrm{i}}$ is the share of commodity purchases from the $\mathrm{i}$-th trader $(\mathrm{i}=1,2,3, \ldots, \mathrm{n})$. When the result is $\mathrm{HHI}=1$ it leads to monopoly or monopsony (Cheung \& Shen, 2017), HHI $=0$ leads to perfect competition, and $0<\mathrm{HHI}<1$ leads to oligopoly or oligopsony.

\section{c. CR4 (Concentration Ratio for Biggest Four)}

CR4 used to determine the concentration degree of the four largest buyers in a market area, so it can be seen generally 
the strength balance of the bargaining position of farmers (sellers) against traders (buyers). According to Naldi \& Flamini (2014) and Ha \& Seo (2013), the $\mathrm{CR}_{4}$ can be solved with the equation:

$$
C R_{4}=C R_{m} \sum_{i=1}^{m} M S_{i}
$$

where $\mathrm{CR}_{\mathrm{m}}$ is the company's concentration ratio of $\mathrm{m}(\%), \mathrm{M}$ is the number of large companies, and $\mathrm{MS}_{\mathrm{i}}$ is the market share of the $\mathrm{i}$-th company (\%). If, $\mathrm{CR}_{4}<0,4$ the market structure is perfect competition (competitive) or monopolistic competition (needs to be seen whether there is product differentiation or not). If $0,4 \leq \mathrm{CR}_{4} \leq 0,8$ the market structure is oligopoly or oligopsonistic, and if CR4 $>0.8$ then the market structure tends to be monopolistic or monopsonistic.

\subsection{Market Behavior Approachment}

Analyzed by using descriptive qualitative with respect to the market, which is the object of this study. In this case, the discussion will be focused on the presence or absence of collusion practices in terms of determining prices analyzed descriptively. The analysis includes the selling and buying process, the formation of equilibrium prices, payment systems (cash or credit), and cooperation with other trading institutions.

\subsection{Market Performance Approachment}

\section{a. Marketing Margin}

Using marketing margin analysis will be obtained the information about shares distribution, the costs required to market potatoes, and the profits that will be received by marketing institutions against total margins from various marketing channels. The equation used in this analysis is:

$$
M=\sum_{i=1}^{m} \sum_{j=1}^{n} C_{i j}+\sum \pi j
$$

Where $\mathrm{M}$ is the marketing margin, $\mathrm{Cij}$ is the marketing cost to perform the $\mathrm{i}$-th marketing function by the $\mathrm{j}$-th institution, $\pi \mathrm{j}$ is the profit of the $\mathrm{j}$-th marketing agency, $\mathrm{m}$ is the number of types of marketing costs, and $\mathrm{n}$ is the number of marketing institutions.

\section{b. Farmer's share}

Share price at the farm level is the costs incurred in the production of potatoes plus the benefits received from the farming business (Bonabana-Wabbi et al., 2013b). The farmer's share can be shown as a percentage, according to (FSTS, 2011).

$$
S P_{f}=\frac{P_{f}}{P_{r}} \times 100 \%
$$

Where $\mathrm{SP}_{\mathrm{f}}$ is the share price at the farm level, $\mathrm{P}_{\mathrm{f}}$ is the price at the farm level, and $\mathrm{P}_{\mathrm{r}}$ is the price at the final level consumer.

\section{Results and Discussion}

\subsection{Market Structure}

Analysis of the potato market structure was carried out with three analysis tools, there are market share, $\mathrm{HHI}$, and $\mathrm{CR}_{4}$. All analysis tools show the same result, oligopsony, wherein this structure there are several buyers who control the market in potato trading. This market structure affects the bargaining position of potato farmers to be weak, farmers as price takers, while the price of potatoes is more determined by traders. Although the structure of the potato market is an oligopsony based on Table 2, farmers and other marketing institutions do not carry out promotions to increase their sales. This is because potato products already have their respective grades, namely grades A, B, C, and rindil. In addition, promotional activities will need costs, while they do not have enough capital to carry out these promotional activities. 
Table 2. Potato market structure for each marketing institution

\begin{tabular}{|c|c|c|c|}
\hline $\begin{array}{l}\text { Market } \\
\text { (Company) }\end{array}$ & Market share (\%) & $\begin{array}{l}\text { Herfindahl-Hirschman } \\
\text { Index }\end{array}$ & $\mathrm{CR}_{4}(\%)$ \\
\hline Collector trader & $\begin{array}{l}58.40 \\
\text { (Loose oligopsony) }\end{array}$ & $\begin{array}{l}0.204 \\
\text { (oligopsony) }\end{array}$ & $\begin{array}{l}58.40 \\
\text { (oligopsony) }\end{array}$ \\
\hline $\begin{array}{l}\text { Wholesaler } \\
\text { (inside and outside the } \\
\text { province) }\end{array}$ & $\begin{array}{l}72,81 \\
\text { (Tight oligopsony) }\end{array}$ & $\begin{array}{l}0.423 \\
\text { (oligopsony) }\end{array}$ & $\begin{array}{l}72.81 \\
\text { (oligopsony) }\end{array}$ \\
\hline Retailer & $\begin{array}{l}54.52 \\
\text { (Loose oligopsony) }\end{array}$ & $\begin{array}{l}0.112 \\
\text { (oligopsony) }\end{array}$ & $\begin{array}{l}54.52 \\
\text { (oligopsony) }\end{array}$ \\
\hline
\end{tabular}

The marketing of potatoes in the highland vegetable production centers in the Central Java region is selling with the pattern of farmer trading - collector traders - wholesalers (inside and outside the province) - retailers. Traders do not make changes to forms that can create added value (form utility). Traders only do the sorting, grading, and packaging to differentiate the price of potatoes according to their grade and then carry out the transportation function to create a place value (place utility).

Information about the price of potatoes at the farm level can be seen at STA (Sub-Terminal Agribusiness) Jakarta and Kejajar, so that they can be shared with farmer groups who are members of the STA. However, farmers rarely access the information, so they often miss the information on potato prices at that time. Weak price information received by farmers affects the bargaining position of farmers to be weak (price takers). The potato price information is more widely accessed by traders. Some traders not only know information about the prices but also about the demand and supply of the potato market the information comes from traders at one level or from traders at the above level.

\section{Market Behavior}

Market behavior related to existing trading institutions, namely potato farmers as producers, collector traders, wholesalers, and retailers includes behavior in the system of price formation, contracts, and collusion (cooperation) between marketing institutions. There is no standard pricing policy from the government to determine the price of marketing highland vegetables. Pricing at the farmer or producer level is more controlled by collectors who deal directly with farmers. While large traders dominate purchases from collectors. The practice of collusion between collectors and large traders occurs especially in the provision of capital or credit.

\section{Market Behavior at Farmer Level}

Most potato farmers sell their products to traders. The sale of potatoes by farmers can be done freely and or implicitly by contract. Free sale (not bound) if the farmer does not have a loan to the buyer (the trader), the farmer can freely sell his potatoes to the buyer who gives the highest price. Otherwise, if a farmer has a loan it means that the farmer has been bound by a contract. Because farmers previously received assistance in the form of cash or production facilities such as fertilizer, seeds, pesticides, and others. In such conditions, farmers cannot choose buyers.

Payments from farmers that buying vegetables in the highland is made in cash or paid later. On purchases that are paid later, the farmer is given a kind of securities in the form of a bill from the buyer which is proof that the potatoes offered will be purchased. This method is considered to be detrimental to the farmers because there is no legal force for claims or compensation if it turns out that the price received by farmers is not in accordance with what was written in the bill. It is clear that the position of farmers is weak in terms of price determination.

\subsection{Market Behavior at the Collector Trader Level}

Collector traders carry out marketing functions of grading and sorting. Collector traders can sell potatoes to wholesalers. Sales to wholesalers are usually done at STA. Payments are made in cash or not in cash, payment in cash is made after going through a bidding process. Pricing is carried out in a balanced manner according to the prevailing market price standards. Formation of prices at the level of traders occurs due to the purchase of potatoes from farmers, generally in small to medium scale. Then the collecting traders sell back to the wholesalers. The capital used for the process of buying vegetables at the farm level is usually assisted by wholesalers, so there is a need for collecting traders 
to sell their vegetables to the capital providers (wholesaler).

\subsection{Market Behavior at the Wholesalers Level}

Potato products that sold to wholesalers generally come from collectors at the STA. The sale is usually made implicitly in the contract because previously the wholesalers had given capital to the traders to buy potato products to farmers. Payment can also be made in cash, this is done by collectors who are not bound by wholesalers or there is no capital tie-up from large traders. In the next stage, potatoes from wholesalers are sold outside the region (in the province or outside the province) and offered to retailers in the market.

\subsection{Market Behavior at the Retailer Level}

Market behavior at the retailer level is simpler because they get a supply of potato products from the wholesaler. The method of payment is made by paying cash or postponed according to the agreement of the two parties that have become subscriptions.

\section{Market Performance}

\subsection{Marketing Margin}

In the marketing system there are several marketing patterns, and in this study 2 patterns will be used. Pattern 1 consists of farmers, collectors, wholesalers (in provinces), retailers, and consumers.

Table 3. Distribution of average price, costs, profits, and margin of Trading System Pattern 1

\begin{tabular}{lll}
\hline Marketing Institutions and Margin & Potato Trading Pattern 1 & \\
\cline { 2 - 3 } & Price (Rp/Kg) & Percentage (\%) \\
\hline Farmers & & \\
Selling price & 9.000 & 60.00 \\
\hline Collector trader & & \\
Buying price & 9.000 & 60.00 \\
Selling price & 11.000 & 73.33 \\
Trading costs & 500 & 3.33 \\
Profit & 1.500 & 10.00 \\
Margin & 2.000 & 13.33 \\
\hline Wholesaler (in provinces) & & \\
Buying price & 11.000 & 73.23 \\
Selling price & 13.000 & 86.67 \\
Trading costs & 1.000 & 6.67 \\
Profit & 1.000 & 6.67 \\
Margin & 2.000 & 13.33 \\
\hline Retailer & & \\
Buying price & 13.000 & 86.67 \\
Selling price & 15.000 & 100.00 \\
Trading costs & 500 & 3.33 \\
Profit & 1.500 & 10.00 \\
Margin & 2.000 & 13.33 \\
\hline Consumer & & \\
Buying price & 15.000 & 100.00 \\
\hline Total Trading Costs & 2.000 & 13.33 \\
Total Profit & 4.000 & 26.67 \\
Total Trading Margin & 6.000 & 40.00 \\
\hline
\end{tabular}

In Table 3 it can be seen that the cost of trading per kilogram of potatoes is greatest for large traders (in the province), 
which includes sorting, grading packing in sacks, and transportation within the province. Meanwhile, the collecting traders only pay for transportation from the land to the warehouse or STA. Likewise, resellers only incur transportation costs from wholesalers to market stalls. The profit that gained per kilogram of potatoes between the collector and the retailer is the same, while the wholesalers get smaller profits. In reality, collectors and retailers sell potatoes in smaller quantities than wholesalers, so that the overall profit is smaller than the wholesalers. Potato trading from prices at farm level to consumers in pattern 1 shows that the total cost per kilogram of potatoes is $13.33 \%$ with a total profit of $26.67 \%$, and the total profit margin of trading is $40.00 \%$.

Table 4. Distribution of average price, costs, profits, and margin of Trading System Pattern 2

\begin{tabular}{lll}
\hline Marketing Institution and Margin & Potato Trading Pattern 2 & \\
\cline { 2 - 3 } & Price (Rp/Kg) & Percentage (\%) \\
\hline Farmers & & \\
Selling price & 9.000 & 56,25 \\
\hline Collector trader & & \\
Buying price & 9.000 & 56.25 \\
Selling price & 11.000 & 68.75 \\
Trading costs & 500 & 3.12 \\
Profit & 1.500 & 9.37 \\
Margin & 2.000 & 12.50 \\
\hline Wholesaler (outside the provinces) & & \\
Buying price & 11.000 & 68.75 \\
Selling price & 14.000 & 87.50 \\
Trading costs & 1.500 & 9.37 \\
Profit & 1.500 & 9.37 \\
Margin & 3.000 & 18.75 \\
\hline Retailer & & \\
Buying price & 14.000 & 87.50 \\
Selling price & 16.000 & 100.00 \\
Trading costs & 500 & 3.12 \\
Profit & 1.500 & 9.37 \\
Margin & 2.000 & 12.50 \\
\hline Consumer & & \\
Buying price & 16.000 & 100.00 \\
\hline Total Trading Costs & 2.500 & 15.63 \\
Total Profit & 4.500 & 28.12 \\
Total Trading Margin & 7.000 & 43.75 \\
\hline
\end{tabular}

Pattern 2 of potato traders is similar to pattern 1 , but the difference is the wholesalers sell potato products outside the province. The cost of potatoes per kilogram at the collector traders and retailers is the same as pattern 1 but in pattern 2 the wholesalers incurring the larger commercial costs for inter-provincial transport. This will have a direct impact on rising costs of potatoes per kilogram from farmers to consumers, so the potato prices for the out-of-province consumers level. Potato traders at pattern 2 from prices at the farmer level to consumer-level showed the total cost per kilogram of potatoes was $15.63 \%$, total profit $9.37 \%$, and total trader margin $43.75 \%$.

\subsection{Farmer's Share}

The farmer's share that received by a farmer is different for each trading pattern. The price of potatoes at the farm level is the same in both the trading patterns, which is Rp. 9.000, -, whereas the value of the farmer's share in pattern 1 is greater than pattern 2 . This is due to the total trading system margins and the price of potatoes at the final consumer level in pattern 1 is lower than pattern 2. 
Table 5. Farmer's share of potatoes trading pattern

\begin{tabular}{llll}
\hline Trading Pattern & $\begin{array}{l}\text { Price at Farmer Level } \\
(\mathbf{R p} / \mathbf{k g})\end{array}$ & $\begin{array}{l}\text { Price at Final Consumer } \\
\text { Level (Rp/kg) }\end{array}$ & Farmer's Share (\%) \\
\hline Pattern 1 & 9.000 & 15.000 & 60.00 \\
\hline Pattern 2 & 9.000 & 16.000 & 56.25 \\
\hline
\end{tabular}

Farmer's share on each trading pattern is affected by some factors, there is a) the cost of the trading system is borne by each trading institution, b) the size of the trading system margins that formed in the trading system pattern; c) profits that determined by each trading institution from the buying price; d) the high or low prices at the consumer level or selling prices at the highest level of trading institution. The smaller trading system margins and the smaller prices at the final consumer level, the greater of farmer's share that received by farmers.

\section{Conclusions}

The structure of the potato trading market in the highland vegetable production center of Central Java province, Indonesia, leads to the oligopsony market. This structure causes the bargaining position of farmers in a weak condition (price taker). Price behavior at the farmer (producer) level is more controlled by collectors who deal directly with farmers. Wholesalers dominate purchases from collectors and payments are made in cash or credit. The practice of collusion between collectors and large traders occurs especially in the provision of capital or credit. Potato traders do sorting, grading, and packaging. The transportation function is to create place utility, while the activity to create form utility is not carried out. For new traders, it will be some obstacles to entering as market players, especially at the level of collector traders and traders. The market performance of potato that based on the trading system margin is greatest in pattern 2 while the farmer's share is greatest in pattern 1 in the potato trading system.

\section{References}

(FSTS), F. S. T. S. / M. O. A. (2011). Marketing Costs and Margins.

Achike, A. I., \& Anzaku, T. A. K. (2010). Economic Analysis of the Marketing Margin of Benniseed in Nasarawa State, Nigeria. Journal of Tropical Agriculture, Food, Environment and Extension, 9(1), 47-55. https://doi.org/10.4314/as.v9i1.57459

Adam, K., Marcet, A., \& Nicolini, J. P. (2016). Stock Market Volatility and Learning. The Journal of Finance, LXXI(1). https://doi.org/10.1111/jofi.12364

Aguiar, G. P., Da Silva, J. C. G. L., Frega, J. R., De Santana, L. F., \& Valerius, J. (2017). The Use of Constant Market Share (CMS) Model to Assess Brazil Nut Market Competitiveness. Journal of Agricultural Science, 9(8), 174. https://doi.org/10.5539/jas.v9n8p174

Bonabana-Wabbi, J., Ayo, S., Mugonola, B., Taylor, D., Kirinya, J., \& Tenywa, M. (2013). The Performance of Potato Markets in South Western Uganda. Journal of Development and Agricultural Economics, 5(6), 225-235. https://doi.org/10.5897/jdae12.124

Brezina, I., Pekár, J., Čičková, Z., \& Reiff, M. (2016). Herfindahl-Hirschman Index Level of Concentration Values Modification and Analysis of Their Change. Central European Journal of Operations Research, 24(1), 49-72. https://doi.org/10.1007/s10100-014-0350-y

Bukar, U., Mohammed, D., Wakawa, R., Shettima, B. G., \& Muhammad, S. T. (2015). Analysis of Market Structure, Conduct and Performance for Pepper in Borno State, Nigeria: A Review. Journal of Agricultural Economics, Environment and Social Sciences, 1(1), 181-190.

Camire, M. E. (2016). Potatoes and Human Health. In Advances in Potato Chemistry and Technology (Second Edi, pp. 685-704). Elsevier Inc. https://doi.org/10.1016/B978-0-12-800002-1.00023-6

Cheung, S. O., \& Shen, L. (2017). Concentration Analysis to Measure Competition in Megaprojects. Journal of Management in Engineering, 33(1), 1-11. https://doi.org/10.1061/(ASCE)ME.1943-5479.0000464

Ebenezer, A., \& Oladipo, E. (2016). Relevance of Structure, Conduct and Performance Paradigm in the Nigerian Banking Industry. Journal of Economics and Sustainable Development, 7(19), 71-81.

Ekunwe, P. A., \& Alufohai, G. O. (2009). Economics of Poultry Egg Marketing in Benin City, Edo State, Nigeria. International Journal of Poultry Science, 8(2), 166-169. https://doi.org/10.3923/ijps.2009.166.169

Eronmwon, I., Alufohai, G., \& Ada-Okungbowa, C. (2014). Structure, Conduct, and Performance of Plantain 
Marketing in Edo State, Nigeria. Journal of Applied Sciences and Environmental Management, 18(3), 437-440.

Ha, Y. S., \& Seo, J. S. (2013). An Analysis of Market Concentration in the Korean Liner Shipping Industry. Asian Journal of Shipping and Logistics, 29(2), 249-266. https://doi.org/10.1016/j.ajs1.2013.08.007

Hirpa, A., Meuwissen, M. P. M., Tesfaye, A., Lommen, W. J. M., Oude Lansink, A., Tsegaye, A., \& Struik, P. C. (2010). Analysis of Seed Potato Systems in Ethiopia. American Journal of Potato Research, 87(6), 537-552. https://doi.org/10.1007/s12230-010-9164-1

Jari, B., \& Fraser, G. C. G. (2009). An Analysis of Institutional and Technical Factors Influencing Agricultural Marketing Amongst Smallholder Farmers in the Kat River Valley, Eastern Cape Province, South Africa. African Journal of Agricultural Research, 4(11), 1129-1137.

Lam, J. S. L., Yap, W. Y., \& Cullinane, K. (2007). Structure, Conduct, and Performance on the Major Liner Shipping Routes. Maritime Policy and Management, 34(4), 359-381. https://doi.org/10.1080/03088830701539149

Lelissa, T. B., \& Kuhil, A. M. (2018). The Structure Conduct Performance Model and Competing Hypothesis- a Review of Literature The Structure Conduct Performance Model and Competing. Research Journal of Finance and Accounting, 9(1), 76-89.

Martin, S. (2012). Market Structure and Market Performance. Review of Industrial Organization, 40(2), 87-108. https://doi.org/10.1007/s11151-012-9338-8

Mcauliffe, R. E. (2015). Herfindahl-Hirschman Index. In Wiley Encyclopedia of Management. John Wiley \& Sons, Ltd. https://doi.org/10.1002/9781118785317.weom080214

Mulyo Aji, J. M. (2016). Exploring Farmer-supplier Relationships in the East Java Seed Potato Market. Agriculture and Agricultural Science Procedia, 9, 83-94. https://doi.org/10.1016/j.aaspro.2016.02.130

Naldi, M., \& Flamini, M. (2014). The CR4 Index and the Interval Estimation of the Herfindahl-Hirschman Index: An Empirical Comparison. SSRN Electronic Journal. https://doi.org/10.2139/ssrn.2448656

Razavi, S. M., Nasirian, M., \& Afkhami, I. (2015). The effectiveness sleep hygiene training on the job performance of employees Shift or rotating shifts parvadeh tabas coal companies in. UCT Journal of Management and Accounting Studies, 3(1), 5-7.

Sadeghpour, F., Far, M. G., Khah, A. R., \& Akbardokht Amiri, M. A. (2017). Marketing Strategic Planning and Choosing the Right Strategy using AHP Technique (Case Study: Ghavamin Bank Mazandaran). Dutch Journal of Finance and Management, 1(2), 45. https://doi.org/10.29333/djfm/5821

Sebatta, C., Mugisha, J., Katungi, E., Kashaaru, A., \& Kyomugisha, H. (2014, July). Smallholder Farmers’ Decision and Level of Participation in the Potato Market in Uganda. Modern Economy, 895-906.

Shepherd, W. G. (1987). Herfindahl Index. In The New Palgrave: A Dictionary of Economics (1st ed.). https://doi.org/10.1057/978-1-349-95121-5

Srinivasan, S. (2011, July). Futures Trading in Agricultural Commodities. SSRN Electronic Journal. https://doi.org/10.2139/ssrn.1197602

Teece, D. J. (2016). Market Structure Research. In The Palgrave Encyclopedia of Strategic Management (pp. 129-164). https://doi.org/10.1142/9789814596480_0006

Vetter, T. R. (2017). Descriptive Statistics: Reporting the Answers to the 5 Basic Questions of Who, What, Why, When, Where, and a Sixth, So What?. Anesthesia \& Analgesia, 125(5), 1797-1802. https://doi.org/10.1213/ANE.0000000000002471

Wang, C., Huang, W., Zhang, B., Yang, J., Qian, M., Fan, S., \& Chen, L. (2016). Design and Implementation of an Automatic Grading System of Diced Potatoes Based on Machine Vision. In IFIP International Federation for Information Processing (Vol. 479, pp. 202-216). Springer International Publishing. https://doi.org/10.1007/978-3-319-48354-2 